\title{
YERKÜREDEN MAVERAYA BİR ÇIĞLIK: MEHMET AKİF
}

\section{AN EXCLAMATION FROM EARTH TO THE BEYOND: MEHMET AKİF}

\author{
Yahya AYDIN $^{1}$
}

$\ddot{O} z$

Mehmet Akif'in şiiri, birçok unsurdan oluşmuş bir halitadır. Şiirlerinin temel vasfi "çı̆̆llk"tır ve yüksek sesle okunması gerekir. Bu "çığllk"ın ferdî (Kısmen I.Safahat), içtimâ̂ (genel olarak II-VI. Safahat) ve maveraî (Genel olarak VII. Safahat) bir kavis izlediği söylenebilir. Selma şiiri, onun şiirinde çok az gördüğümüz ferdî bir çı̆̆llk ve haykırışın ifadesidir. Zaten Akif, daha sonra neredeyse ferdî konulu şiirler yazmaz. Bu şiir, bir bakıma "hazin bir veda" ya da "yürek burkan vaveyla"dır. Sanatının esas zembereğini içtimầ meseleler kurar. Hakkın Sesleri, şairin ayet ve hadislerden hareketle bir kalkış noktası belirlediği şiirleri ihtiva eden kitabıdır. Balkan Savaşları ve sonrasinın anlatıldığ "Geçenler varsa İslâmın şu çiğnenmiş diyarından” misralyla başlayan şiir, Rumeli’nin yakıp yıkılmasını, bunda Müslümanların içine düştüğü yeis ve ataletin payını vurgular. Mısır'da iken yazdı̆̆ Hicrân şiiri ise, türlü saiklerle yüzünü öte dünyaya çevirdiği verimlerindedir. Tasavvufì pırlltılar aksettiren bu şiirde ise gurbet (ülke-memleket/ahiret yurdu-Allah) ve bundan kaynaklan hicran maveraî bir çığllk olarak karşımıza çıkar.

Anahtar Kelimeler: Türk Şiiri, Mehmet Akif, Çı̆̆llk.

Abstract

Mehmet Akif's poet is a composition which has a lot of components. Characteristic of his poetry is an exclamation and his poetry need to be read aloud. It can be sayable this exclamation is a curve that individual (partly I. Safahat), social (generally II-VI. Safahat) and the beyond (generally VII. Safahat). The poetry "Selma" is a statement of individual exclamation and bawling that we can see rarely. This is " a pathetic farewe ll” or "a heart rending uproar ". Social issues instal the essence spring of his art. His book "Hakkın Sesleri" comprises his poems which he designed starting point from verse of the Koran and hadith. The poem which begins "Geçenler varsa İslâmın şu çiğnenmiş diyarından” depicts Balkan Wars

\footnotetext{
${ }^{1}$ Yrd. Doç. Dr., Düzce Üniversitesi Eğitim Fakültesi, Türkçe Öğretmenliği Bölümü, yahyaaydin@duzce.edu.tr.
} 
and the aftermath, the demolition of Rumelia and the responsibility of Muslims who were in despair and in stagnance. The poem hicran which he wrote in Egypt is opus from times he faced the beyond for a variety of reasons. In this poem, reflecting sufistic twinkle, foreign land (province-native region/afterlifeAllah) appears as a beyond scream originated from seperation.

\section{Keywords: Turkish Poetry, Mehmet Akif, Exclamation.}

\section{GİRIŞ}

Modern Türk şiirinin oluşumunda, üzerinde durulması gereken isimlerin başında Yahya Kemal, Ahmet Haşim ve Mehmet Akif’in geldiği araştırmacıların hemfikir olduğu hususlardan biridir. Yahya Kemal ve Ahmet Haşim, kaynakları farklı olsa da saf şiir vadisindeki verimleri ile modern Türk şiirine giden yolun yapı taşlarını döşerlerken, Mehmet Akif de realist bir tavırla bu oluşuma katkı sunan örnekler ortaya koymaya devam eder.

Yukarıda zikrettiğimiz isimlerden Mehmet Akif'in, modern şiirin amaçlarından birini, "konuşma dilindeki doğallığın şiir dilinde ifade edilmesini (Eroğlu, 2011: 25)." büyük bir yetkinlikle başardığı görülür ${ }^{2}$. İlk olarak Recaizade Ekrem'de örneklerini gördüğümüz bu tavır, Tevfik Fikret'le devam eder. Bu bağlamda Servet-i Fünun sanatçılarının Batı'dan aldıkları "anjambıman” tekniğinin de bu amaçla birçok şair tarafından kullanıldığı görülür. Mehmet Akif şiirinde önemli bir yer tutan "Manzum hikâye" tarzı, bu tekniğin bir tezahürüdür (Gökçek, 2005: 30). Bu tarzı, Akif'in aruzun imkânlarından da yararlanarak Türkçeye başarılı bir şekilde uyguladığı ortadadır.

Akyüz (1999: 139) şiirimize gerçek realizmin Akif’le girdiğini, onun kuvvetli gözlemciliğini, büyük bir tasvir ve tahkiye kabiliyetini, konuşma dilinin bütün canlılığını taşıyan üslûbunu vurgular ama tasvirlerinin dışında kalan birçok şiirinde, “dil”’inin konuşma dilinden ayrılıp Osmanlıcanın sınırları içine girdiğini iddia eder ${ }^{3}$. Akyüz’ün bu tespitlerinde çok az haklılık payı vardır. Zira Akif Arapça, Farsça ve Fransızcayı çok iyi bilmesine rağmen, dilde “yerlilik”ten taviz vermez ${ }^{4}$. Mehmet Akif'in lisan konusundaki bu bilinçli tavrı, 24 Şubat 1327 tarihli Sebilürreşad dergisinde yayımlanan "Edebiyat" adlı makalesinde açıkça görülür. Mehmet Akif, "sade yazmak bizim için asıldır. Ne zaman bu asıldan ayrı düşmüşsek, mutlaka çaresiz kalmışızdır. Yalnız sadelikte 'cennet'i beğenmeyip 'uçmak', 'cehennem’i bırakıp ‘tamu' diyecek kadar ileri gidecek değiliz (Akif, 2011: 109).” diyerek bu konudaki görüşlerini

\footnotetext{
${ }^{2}$ Yahya Kemal (2010: 109-126), Vezinler I-II adlı yazılarında Tevfik Fikret, Cenab Şehabettin ve arkadaşlarının eski şiirimizi nesre yaklaştırıp saz hâlinden çıkardıklarını, Mehmet Akif’te görüldüğü gibi de söz hâline koyulduğunu belirtir. Ona göre aruz, Türkçede Tevfik Fikret'le beraber sokakta ve evde konuştuğumuz gibi konuşmaya başlar. Sonra da onun "felsefede muarızı olduğu derecede sanatta muakkibi olan" Mehmet Akif'in elinde büsbütün yumuşar. Yahya Kemal, bu vetireyi bir tekâmül olarak değil bir atlayış olarak görür.

Sevük (1930: 363), Mehmet Akif'in, nesirde Muallim Naci’nin yaptığını, nazımda “yalnız sade ve temiz Türkçeyi değil, bütün İstanbul şivesile Türk hançeresini aruza mıhlayacak tarzda” yaptığını, bu yönüyle onun, Muallim Naci’yi ikmal eden bir tekâmül olduğunu belirtir. Sevük, aynı zamanda Akif’te bu yönüyle koyu bir Türkçülük bulunduğuna işaret eder. İsmail Habib, Tevfik Fikret'in de "aruzu Türkçeye intibak ettirmek" noktasında önemli katkıları olduğunu ama Fikret'in, Âkif kadar, "İstanbullu olduğu halde kendi nazmına İstanbul şivesini daha doğrusu Türk hançeresini” tamamen koyamadığını ifade eder.

${ }^{3}$ Eşref Edib (1960: 12-13), Akif' in yazılarına karşı Rusya Türklerinin gösterdiği ilginin temelinde, yazılarının ihtiva ettiği manaların yüksekliğini ve "gayet temiz, açık bir Türkçe ile yazılmasını" gösterir. Eşref Edib, onu diğer şair ve yazarlardan ayıran bir vasıf olarak "her sınıf halk onun eserini anlar, onun eserinden zevk duyar (...) En yüksek fikirlerin en sade, en açık Türkçe ile ifade olunabileceğini her zaman söyler, her zaman da yazılarıyla ispat eylerdi." der.

${ }^{4}$ Mithat Cemal Kuntay (2001: 336-339), dostu Akif'in güzel Türkçenin üstüne titrediğini ve onun "din"inden sonra "dil”'inin geldiğini aktarır. Arapça ve Farsçayı çok iyi bilmesine rağmen, onun şiirlerinde, Arapça ve Acemce’yi hiç bilmeyen bir adamın sadeliğini gördüğünü belirten Mithat Cemal, bunu Akif' in şuurlu olgunluğuna bağlar. Safahat'ın 6 bin mısradan müteşekkil yapısı içinde "Arapça kelimelerin Arapça istimalleri, ancak beş on kelimeye, Arapça ve Acemce terkiplerin varlığı da bir iki yüz mısraa münhasırdır" diyen Kuntay, Akif'in bu tavrını şöyle niteler: "Elmaslarını takmayacak kadar zengin olan kadının sadeliği!..” Lisan konusu Akif'te mühim bir yer tutar. Onun hayatını lisandan, lisan öğrenme cehdinden ayrı tutmak imkânsızdır. Bu itibarla Dücane Cündioğlu (2007: 15-97) da Bir Kur'ân Şairi Mehmet Âkif ve Kur'an Meali kitabında, Akif'in biyografisini, "Lisanî Biyografisi"” başlığı altında vermeyi tercih etmiştir.
} 
ortaya koyar. Zaten dilde sadeleşmenin yavaş yavaş olacağını, Safahat'ta aşama aşama bunun görülebileceğini söyler (Edib, 1960: 258-259). Bu noktada Akyüz’ün yaptı̆̆ı değerlendirmenin genel olarak yerinde olmadığı açığa çıkmaktadır. Son tahlilde Akif'in dili çağdaşlarına göre sade, açık ve anlaşılır bir niteliğe sahiptir.

Akif, edebiyatımıza o güne kadar görülmeyen "şiirle düşünme” biçimini sokmuş, safahatıyla modern Türk şiirinde müstesna bir yer kazanmıştır. Karakoç (1978: 42)'a göre Akif kadar, "Bir dönem fikriyle donanmış olarak, belli bir dünya görüşünün ışı̆̆ında, geniş anlamdaki kronikler hâlinde, safha safha bir kuşağın dramını veren, ilk bakışta zıt, realist çizgilerle mitleşmeye elverişli davranışlarını kaynaştırarak canlandıran böyle bir başka realizm ve destan şairimiz yoktur." Akif'in şiiri ancak döneminin sosyal, siyasal gelişmeleri yakından bilinirse, iyice anlaşılabilir. Ahmet Haşim’in aksine cemiyet hayatının tam ortasında şiirini kuran Akif, Mehmet Kaplan (2013: 174)'ın ifadesiyle “Türk edebiyatında içinde yaşadığı devri (...) bütün teferruatı ile gören ve gösteren bir şair[dir]." Safahat'1 "muayyen bir nokta-i nazardan tasvir edilen bir manzum romana" benzeten Kaplan, onun şiirinin, hududunu nesir kadar, edebiyat kadar genişlettiğini son tahlilde edebiyatı da aşıp hayatın kendisi hâline geldiğini ileri sürer ${ }^{5}$. Kimi araştırmacılar ise onun şiiri ile hayatının birlikte yürüdüğünü savunur ${ }^{6}$.

Mehmet Akif' in şiiri belli bir dünya görüşünün 1şı̆̆ında yazılmıştır. Onun şiiri, her şeyden önce, “Din-Kur'an” merceğinden dünyaya bakan bir şairin şiiridir". Birçok şiirinde ayet ve hadislerin manaları ya doğrudan verilir ya da şiirin dokusu içinde eritilir. Topçu (1970: 31-32), Mehmet Akif'te din ve dindarlık idealinin "sanat vecdinin tabiî bir ilerleyişi ile birlikte” geldiğini ifade eder. Ona göre Akif” in, “aşk ve ilham perisi”" Kur'an'dan gelmektedir. Akif, din idealinde hem kendini aramış hem de milletinin selâmetini bulmuştur. Kendi kurtuluşu da zaten "ruhunun selâmeti dâvası ile milletinin selâmeti dâvası"ndan mürekkeptir ${ }^{8}$

\footnotetext{
5 Enginün (2004: 147) de Akif'in cemiyet meseleleriyle yakından ilgilendiğini, özellikle sosyal şiirlerinde acıma duygusu uyandırmak ve kötümserliğini gözler önüne sermekten ziyade, sorunu teşrih masasına yatırmak ve ona çözüm bulmak isteğinin ön plan çıktığını kaydeder. Bunu yaparken de halkın karşısında nutuk çekerek bulunmaz, içinde ve onun ağzıyla konuşur.

${ }^{6}$ Gökçek, F.(2013), Bir Medeniyetin Şairi Mehmet Âkif, Ankara. TDK Yayınları. s.12.

${ }^{7}$ Kuntay (2001: 241), Akif'in sanatı ve seciyesinde Kur'an'ın teşkil ettiği yeri şöyle belirtir: “Cevdet Paşa Kur'an nâsiridir, Akif Kur'an şairi. Ancak ikisini arasında fark var; Kur'an Cevdet Paşa'nın yalnız kültürünü, Akif' in kültürüyle beraber seciyesini de yapt1."

Süleyman Nazif, 1926 yılında “Kur'an”ın Türkçeye tercümesi işinin Akif'e verildiğini duyunca, bundan duyduğu memnuniyeti izhar eder. İlim, aşk ve iman isteyen bu ișin ancak Akif tarafından başarılabileceğini ifade eden Süleyman Nazif, "Kur'an'ı Cenab-1 Hakk, Türk lisanıyla inzâl etmeyi murad etseydi, Cebrâil’i, bî-şüphe Safahat Şâiri olurdu.” diyerek, düşüncesini ortaya koyar (Süleyman Nazif’ten aktaran: Cündioğlu, 2007: 15).

Akif hakkında hayatta iken yayımlanan tek kitabın sahibi Süleyman Nazif, Mehmed Âkif adlı eserinde Safahat'ın "Hâtıralar" başlığını taşıyan beşinci kitabının son şiiri olan ve "Şerif Ali Haydar Paşa Hazretlerine" atfettiği Necid Çöllerinden Medîne'ye (Safahat, 2010: 307-313)" şiiri için şunları söyler: "Bunu yazmak için yalnız Mehmed Âkif kadar şâir olmak kifâyet etmez; Mehmed Âkif kadar dindar olmak lâzımdır (Nazif, 2015: 43).”

${ }^{8}$ Her ne kadar çalışmamızın muhtevası Akif' in şiirine dair olsa da, onun hayatı ile şiiri arasında yukarıda belirttiğimiz mütekabiliyet ve hayatının iki muharrik kuvveti olarak da "din” ve "dil”i gösterebileceğimizi düşününce, Akif hakkında, teşrik-i mesaide bulundukları Mehmet Erișirgil'in "İslâmcı Bir Şairin Romanı” adlı kitabında belirttiği bir meseleyi vuzuha kavuşturmak yerinde olacaktır. Öncelikle Akif, İbnülemin Mahmud Kemal İnal'ın (1988: 91), hocası olan Mehmet Akif'in babası İpekli Hoca Tahir Efendi hakkında "Salih, fadıl, vefi, sahi, âlicenap, mürüvvetkâr, müstakim bir üstadı kâmil”; annesi için de "hüsni ahlak sahibi muhterem bir hanım" dediği ebeveynlerin himayesinde yetișmiștir. Ayrıca Akif, uzun mesafeler yürüyebilen, güreşen ve sağlıklı yaşamak için her sabah soğuk suda yıkanan birisidir. Bununla birlikte, 1923 yılında Abdülaziz Çaviş'in Âsâr'ul Hamr adlı risalesini, İçkinin Hayat-ı Beşerde Açtığ Rahneler adıyla Türkçeye çevirmiş, bazı şiirlerinde, örneğin Meyhane, bu içtimai yarayı teșrih masasına yatırmıștır. Hâl böyleyken, Erișirgil, sözü edilen kitabında, kendisini haksız yere ișten çıkardıkları için istifa eden ancak onun geri alınması kaydıyla bundan vazgeçen, karakter salabeti dost düşman herkesin aşina olduğu Akif hakkında, alkollü içki kullandığını, bundan ötürü dostlarından Naim Bey’le șiddetli kavgası neticesinde, bir daha içmeye tövbe ettiğini söyler (Erişirgil, 1986: 216-406). Söz konusu sayfalarda Erişirgil, Tevfik Fikret’in de önceleri ne kadar dindar olduğunu ortaya koymaya çalışır. Yazarın da yaptığı gibi edebiyatımıza bu tür hizipleşmelerin adesesinden bakmak, edebiyatı, edebîliği ıskalamak demektir. Son tahlilde Tevfik Fikret de Akif de Türk edebiyatının önemli isimleridir.
} 
İslâmcılık düşüncesi, Akif'in şiirinde büyük bir yer tutar. İslâmcılık, her şeyden önce bir modernleşme hareketidir' ${ }^{9}$ Karakoç (1978: 19-20)'a göre Akif'in İslâmcılığı, Efganî, Abduh ${ }^{10}$, Ferit Vecdi, Reşit Rıza, İkbal vb. düşünürlerden izler taşır. Bu isimlerin bazı eserlerini Türkçeye tercüme eden Akif, kesinlikle İslâmcıların Türkiye'deki “müdafii ya da şairi” değildir. Çünkü Türkiye'deki İslâmcılık düşüncesinin doğuşuyla, diğer ülkelerdeki doğuş şartları apayrıdır. Türkiye'deki İslâmcıları "çekirdekten yetişme" olarak niteleyen Karakoç, diğerlerinde de "sistem ve düşünce tutarlılığının” geliştiğini belirtir. Akif fikirlerini, bu düşünürlerden ziyade "sokaktan, aileden klasik kültürden, toplumdan, devletin sarsıntılı hâlinden ve nihayet kendinden almıştır." Bir araştırmacının da belirttiği gibi Akif, "İslâm devleti birliğinin savunucusu" anlamında bir İslâmcı ya da panislâmist değildir. Akif bir Müslümandır ve imanının gereğini yapmıştır. Aksini iddia etmek, "saf bir iman hayatına ideoloji bulaştırmak” anlamına gelir (Yetiş, 1992: 206). Akif'in Berlin'de bulunuşunu, Necid çöllerine ${ }^{11}$ gidişini, Milli Mücadele için fikrî ve fizikî mücadelesini hep bu çerçevede değerlendirmek icap eder.

Yakın dostu ve Şehnâme yazarı Mithat Cemal Kuntay (2001: 251)'a göre Akif, “terennümün değil, çığlığın virtüözüdür.” Akif’in şiirlerinin sessiz okunmayacağını ileri süren Kuntay (2001: 419), "hayatının farikası isyandır, şiirlerinin mevzuu da menfi” diyerek Akif'in sanatına asıl rengini veren nitelik ve kavramları ortaya koyar. Bu isyan ve çığlık, Safahat'ın yedi bölümünde de çeşitli meseleler, vesileler ve yönleriyle karşımıza çıkar.

Cemil Meriç, Kültürden Irfana (2013: 269-272) adlı kitabında yer alan Tevfik Fikret ve Akif’i ele aldığı "İki Düşman Kardeş” adlı yazısında, “Akif için şiir samimiyettir. Taine’nin dediği gibi 'sanat

\footnotetext{
9 Okay (2010: 157-158), Mehmet Akif'in “Doğrudan doğruya Kur'an'dan ilham alıp, İslâm'1 asrın idrakine söyletmek" mısraının İslâmcılığın önemli bir şiarı olduğunu belirtir. Ona göre Akif’in “Batı medeniyetini Doğu’ya üstün kılan bütün ilimleri, tekniği, sanayii hatta İslâm ahlâkına aykırı olmamak şartıyla yaşama tarzını benimsemek hususundaki fikirleri İslâmcılığın önemli bir parçasını teşkil eder." Okay, "Batı kültür ve medeniyetini tanımak ve ondan faydalanmak" hususlarında İslâmcıların, Türkçüler ve Batıcılarla ortak bir noktada buluştuğunu ifade eder.

Mehmet Akif' in de önemli isimlerinden biri olduğu İslâmcılık, “... aktivist, modernist ve eklektik yönleri baskın siyasî, fikrî ve ilmî çalışmaların, arayışların, teklif ve çözümlerin bütününü ihtiva eden bir hareket (Kara, 2011: 17)” olarak tanımlanmaktadır. Yine Kara (2012: 189-201) Akif' in "modernleşmenin şartlı savunucusu” olduğunu ifade ederken, Peter L. Berger'in "modern durum ve tavır alışla geleneksel durum ve tavır alıș" arasındaki farkları ortaya koyduğu bir anekdottan hareket ederek, İstanbul'u kasıp kavuran bir kolera salgının yaşandığı 1911 yılında Sıratı Müstakim yazıhanesine gelen bir mektup ve Akif'in bu mektuba verdiği bir cevap yazısından bahseder. Gelen mektupta, kolera salgınına önlem olarak, para ile hafizlar tutulup memleketin etrafının devrettirilmesi önerilmekte, bu teşebbüsün unutulduğundan şikâyet edilmektedir. Akif, bu usulün öncelikle "hiçbir vakit dindarâne" olmadığının altını çizer. Bu teşebbüsün, "mevkiini tahkim için” hükümetin (II. Abdülhamit Dönemi) amaçlarına hizmet eden bir düşünceden neşet ettiğini belirtir ve sözlerini, devrin birçok Müslüman aydını gibi sekülarizmin merkezinden konuşur: "İyice bilmeliyiz ki gerek münferit gerek sâri ne kadar hastalık varsa izalesi için tababetin tavsiye edeceği tahaffuzî, şifaî tedâbirden yapılacak bir șey yoktur."

Gotthard Jaschke (1972: 17), Akif' in eserlerinden bazılarını Türkçeye çevirdiği Muhammed Abduh'un etkisiyle skolastik düşünceden erkenden ayrıldığını ifade eder.

Cerrahoğlu (1964: 6) Akif'in İslâmcılığını anlatırken, "Muhafazakâr reformatör" ibaresini kullanır. Buna göre Akif "geçmişten gelen denge bozulmasın; değişme olsun; ve fakat, bu değişme makul sınırları aşmasın." düşüncesine sahiptir.

${ }^{10}$ Cerrahoğlu (1964: 12) Karakoç’un aksine Akif'in fikri formasyonunda Şeyh Muhammed Abduh'un büyük etkisi olduğunu belirtir. Ona göre Abduh, Akif'in ilham perisidir. Safahat'ın bazı yerlerinde "Şair susar; ve onun yerine, merhum Mısır Müftüsü, mevzun ve mukaffa, konuşur." diyerek, bu etkilenme düzeyini abartır.

${ }^{11}$ Cemal Kutay (1963: 4), Mehmet Akif'i yakın dostu Teşkilât-1 Mahsusa reisi Kuşçubaşı Eşref ile bu seyahate icbar ve ikna eden sebepleri şöyle ifade eder: "Kalbindeki tertemiz vatanseverlik duygusu ve ruhuna hâkim ideallere menfaatsiz, ivazsız hizmet cehdi, Mehmet Akif'i hayatında en yakın 'mefkûre arkadașı"nın delaletiyle bu hadiselere karıștırdı." Akif için bu seyahat "bir teselli ve ruhî huzur" olmuş aynı zamanda "Safahat'ın en zengin ve lirik bölümü” de bu yolculuk neticesinde oluşmuştur. Vatan sevgisi ve vatana hizmet aşkıı, Akif'i bu yolculuk gibi birçok fedakârlığa sevk etmiştir.

Akif'in vatan sevgisi ve vatana hizmet aşkı aile üyelerine yazdı̆̆ı hususî mektuplarında da görülebilir. Hakkari'ye tayini çıkan ve gitmekte tereddüt eden kızı ve kocasına yazdığı mektup, onun engin vatan sevgisinin belgesi niteliğindedir: "Evlâdım Ahmet Bey, (...) Şarka azîmet için hazırlanmak emrini almıșsınız. Rabbim hayırlı eylesin. Hamd olsun gençsiniz, dinçsiniz. Yurdun her tarafını dolaşmalı, her tarafına hizmet etmelisiniz. Vatan bir külldür ki tecezzi kabul etmez: şarkı garbı, şimâli, cenubu, kâmilen nazarımızda bir olmalıdır. Uzak yakın, soğuk sıcak dememeli, elimizden geldiği kadar, hatta bunun fevkinde olarak fedakârâne çalıșmalıyız. Başka türlü ne yașamak, ne memleketi yașatmak imkânı yoktur. Allah mübârek yurdumuzu sizin gibi fedâkâr, vefâkâr evlâdına, sizin gibi fedâkâr, vefâkâr evlâdını da mübârek yurdumuza bağışlasın, âmîn (Mehmet Akif Ersoy'un Aile Mektupları, 2010: 51)."

“Gönüllü sürgün” Akif, Mısır'da hasta ve yokluk içinde iken, askerlik çağına gelen oğlu Emin’i, bizzat Konsolosluk şubesine giderek vatan borcunu ifa etmesi için askere göndermek için gerekli işlemleri başlatır. Emin, Türkiye'de askerliğini yapar
} (Coşkun, 2015:87). Bu durum da Akif'in kuvvetli vatan sevgisi ile açıklanabilir. 
bir çı̆̆lıktır.' Çok kere acı, arada bir ümit dolu çı̆̆lık." ifadelerini kullanır. Karakter abidesi şairi, "tufana yakalanmış bahtsız bir toplumu gemisine çağıran bir nevi Nuh Peygamber” olarak kabul eden Meriç, onun hem bir ülkenin hem de bütün bir kıtanın sesi olduğunu belirtir. Bu açıdan Safahat'ın alametifarikası olan bu "çığglı̆ga kulaklarımızı ve gönlümüzü açık bulunduramazsak hatalarımızın sonu gelmez." diyerek okuyucuları uyarmayı da ihmal etmez.

Mehmet Akif'in sayhaya benzeyen isyanı devrinin sosyal, siyasal, ekonomik ve kültürel gelişmeleri ile yakından ilgilidir. Zaman zaman iç içe geçmelerine ve kaynaşmalarına rağmen sanat telakkisi, yazma tekniği ve lisan karşısındaki tutumu, bu çı̆̆lığın dış yapı unsurlarını oluştururken Kur’an ve iman anlayışı, vatan sevgisi ile müspet ilimler karşısındaki tavrı da muhtevasını kurar.

Mehmet Akif' in Safahat'ındaki çığlık yahut feryadın genel olarak ferdî-içtimai-metafizik bir yön izlediği söylenebilir. Her şeyden önce bu şiirler, bir şair tarafından dile getirildiği için bir ferdî tahassüs ve fikirler yumağıdır. Bunun yanı sıra toplumun ve milletin buhranlı zamanlarına, yöneticilere, yozlaşmış düşüncelere, atalete, ümitsizliğe ve geleceğe dönük bir isyan ve haykırıştır. Bazıları Birinci Safahat'ta yer alan ama çoğunluğu hayatının son yıllarında yazdığı şiirleri ise, ülfetten uzlete çekilmeye mahkûm edilmiş, artık gözünü maveraya çevirmiş merdümgiriz bir şairin öte âleme seslenen verimleridir.

Akif'in, Birinci Safahat içinde yer alan şiirleri aynı zamanda "bütün Safahat'ın konu/tema fihristi” gibidir (Yetiş, 2006: 84). Mehmet Akif'in sayı olarak en çok şiirinin yer aldığı bu kitap "safahat-1 hayat" iddiasını doğrulayacak tarzda toplumun çeşitli kesimlerinden birçok insan manzarasına yer vermektedir (Gökçek, 2013: 26). Zaten Birinci Safahat'1n ilk üç şiiri olan "Fâtih Câmii, Hasta, Tevhîd yâhud Feryâd" yukarıda belirttiğimiz ve Akif şiirinde önemli bir özellik olan çığlığın, genel olarak, bize döngüsel karakterini verirler.

$\mathrm{Bu}$ çalışmanın amacı, Safahat'tan hareketle Mehmet Akif şiirinin temel vasıflarından biri olan “çı̆̆lık”ın sebeplerini irdelemek, yansımalarını saptamak ve hangi alanlarda yoğunlaştığını belirlemektir. $\mathrm{Bu}$ araştırmada nitel araştırma yöntemi tercih edilmiş olup doküman incelemesi tekniği kullanılmıştır. Veriler ise içerik analizi yöntemiyle çözümlenerek, "çı̆̆lık" teması, kavramı etrafında tartışılmış ve elde edilen sonuçlar aşağıda belirtilmiştir.

Bütün Safahat’ı “çı̆̆lık” kavramı eşliğinde okunabilecek Akif’in, ferdî-içtimai ve metafizik özellikler taşıyan ve şiirlerinin döngüsel karakterini bize veren birer şiirini, aşağıda incelemeye çalışacağız ${ }^{12}$.

\section{SELMA: YÜREK BURKAN VAVEYLA YA DA HAZİN BİR VEDA}

Birinci Safahat'ta yer alan merhum İbrahim Bey, Bir Mersiye ve Selma şiirleri ile Yedinci SafahatGölgeler'de yer alan bazı şiirler, Akif'in yakınlarının ve dostlarının ölümü dolayısıyla kaleme alınmış şiirlerdir (Gökçek, 2011: 96). Bu şiirlerden Selma, "bir annenin çı̆̆lığına eklenmiş bir çı̆̆lık gibi” hâlâ inleyip durmaktadır (Düzdağ, 1987: 30). Bu şiirde Akif'in "bir sefalet bir felâket levhasını tasvirde"

\footnotetext{
${ }^{12}$ Fatih Arslan (2011: 259-264) genelde Safahat'ın özelde İstiklâl Marşı'nın taşıdığı metaforik anlam zenginliğine dikkat çeker, Akif'i de dilin bu sırrına erişmiş bir şair olarak niteler.

Sinan Çitçi (2013: 225-255), Akif' in şiirlerini “ağlama motifi” açısından incelemiş ve dikkat çekici sonuçlara ulaşmıştır. Yazara göre Akif, maddi ve manevi felaketlerden korunmak için ne yapılması gerektiğini çeșitli vesilelerle dile getirmiş bir şair de olsa belki imkân ve kudreti elvermediği için, bu olaylar karşısında bedenen değil söyleyerek ve buğz ederek mücadele etmek yoluna gitmiștir. Sözle mücadelesinde de çok başarılı olduğu söylenemeyecek Akif, özellikle kalbiyle buğz etmeyi ve ağlamayı tercih etmiştir. Araştırmacının belirttiğine göre Akif şiirinde üzüntü kaynaklı ağlamalar, üç başlık altında toplanabilir. Bunlar; ilk olarak günlük, sosyal meseleler için ağlamalar; ikinci olarak "devlet, millet, ümmet ölçeğindeki meseleler" karşısında ağlamalar, son olarak da "ulvî ve tasavvufî hislerle" ağlamalar şeklinde sıralanabilir.
} 
büyük bir başarı gösterdiğini belirten Mahir İz (2014: 293), aynı zamanda bu eserin "anaların çocuk bakımıyla yeteri kadar ilgilenmediğini” ortaya koyan bir içtimai ders olduğunu ifade etmiştir.

"Hemşîrezâdemdir.

Dört yaşında öldü (Safahat, 2010: 49) ${ }^{13}$."

şeklinde yalın bir epigrafla başlayan şiir, oldukça karmaşık bir mevzu olan ölüm karşısında takınılan bu tavırla insanı âdeta çarpar. Şiir boyunca ölüm karşısında Mehmet Akif’in tabii tavrını yansıtan bu epigraf, hemşiresinin, çocuğunun ölümü karşısında duyduğu iç paralayan, yürek burkan duyguların tam karşısındadır.

Geçimini temin etmek için, hayat denilen "ceng-i maişet”e, “ma'reke”ye dalan şair, türlü sıkıntılardan kurtulmak amacıyla evinde dinlenmeye çekilir. Ama "dünyanın cefasından sefasına sıra gelmez." fehvasınca, bu istirahati bölünür. Daha önce dört çocuğunu kaybetmiş olan hemşiresinin çocuğu ağır hastadır. Şair, annesinin çağrısına uyarak "âşiyân-1 perîşâna” doğru yollanır. Şair'in annesi, onun, ölüm döşeğinde yatan "pembe pembe yanakları kireç kesilen” çocuğu görmemesini ister. Çünkü dayanamayacağını düşünür.

Şair, bu ağır hastayla ilgili bilgileri annesinden öğrenir. "Anlayışlı" diye bel bağlanan hekimlerin “sersem” çıktığını, “tesellî” vermesi beklenen hekim ilaçlarının ancak Allah tarafından bağışlanan bir “tecelli” olduğunda işe yarayacağını dile getiren valide, çocuğunun hastalığı karşısında kızının laf dinlemeyip kendisini "helâk ettiğini” bu yüzden "şâyân-1 merhamet” bir hale düştüğünü söyler. Akif, hemşiresini "Benim sözüm ne kadar da olsa başkadır” diyerek teselli etmek ister. Ama validesi böyle bir durumda hemşiresinin Akif’i duymayacağını söyler.

“(..)

-Nasıl da söylersin!

Lâkırdı kâr edecek kim? Duyar mı hiç beriki?

Kolay bir iş mi? Senin anne olduğun var mı?

Çocuk o halde iken anne sözden anlar mı (Safahat, 50)?”

Dava evvel dört çocuğunu da kaybeden Akif’in hemşiresi, beşinci çocuğu da ölüm döşeğinde olunca kendini iyice hırpalamış, "kendini vaktinden evvel öldürecek” bir psikolojiye girmiştir. Ölüm döşeğindeki Selma'nın durumu ise, Akif' in annesini bile tuğyana sevk etmiştir.

“(...)

Çıkıp da gör hele bir kerre şimdi Selmâ'yı...

Ne hâle koydu felek, git de bak, o sîmâyı!

Sabahleyin dili, baktım, biraz ağırlaşıyor...

Melil melil bakıyor şimdi bülbül evlâdım!

Ne zâlim illet imiş: Bir çocukla uğraşıyor...

O olmasaydı da keşke ben hasta olsaydım.

Şikâyet olmasın amma tahammülüm bitti...

\footnotetext{
${ }^{13}$ Bundan sonraki alıntılar, M.Ertuğrul Düzdağ’ın neşre hazırladığı ve TDV tarafından basılan Safahat'ın 2010 baskısından yapılacaktır. Yapılacak alıntılarda sayfa numarası vermekle yetinilecektir.
} 
Günâha girmedeyim durmuşum da bak şimdi (Safahat, 50)!”

Ölüm sarhoşluğu "bir kuş kadar uçan o melek” yavrunun bütün uzviyetine hâkim olmuş; hareketsiz, gözlerinin feri sönmüş, ay renkli yüzü toprak rengine dönmüş bir vaziyette yatarken, başında annesi "-mâtem tecessüm etmiş de/Kadın kıyâfeti almış gibi-" sessizce beklemektedir. Şair odaya girince "hurûşa âmâde" komşu kadınlar, ayağa kalkar ama anne ve kızı yatağa mıhlıdır. Kendi itikadınca, ölümle ilgili birtakım açıklamalar yapar. Aslında böyle bir manzara karşısında sözlerinin "âvâre bir talâkat" olduğunun bilincindedir. Nihayetinde annenin söylediği söz, böyle bir durumda söylenen bütün sözlerinin anlamını fersudeleştirir.

"Dedim: Nedir bu senin yaptığın, düşünsene bir.

Bırak şu hastayı artık biraz da kendisine.

Ne çâre, hükm-i kader âkıbet zuhura gelir,

Cenâze şekline girmekte böyle fâide ne?

Senin bu yaptığın Allâh'a karşı isyandır;

Asıl felâkete sabreyleyenler insandır...

Şu yolda başlayan âvâre bir talâkatle,

Devâm edip gidiyorum ben ictihâdımda...

Ne oldu, hastaya bir şey mi oldu, anlamadım...

O beht içindeki kızdan kemâl-i şiddetle,

Şu sayha koptu ki hâlâ enini yâdımda:

'Ne taş yüreklisiniz... Âh gitti evlâdım (Safahat, 51)!.."

\section{3. İÇTIMAİ BİR ÇIĞLIK OLARAK HAKKIN SESLERİ'NDEN BİR FERYAT}

Mehmet Akif'in ölüm temalı şiirlerinden olan Selma, Mehmet Akif şiirinde pek göremediğimiz ferdî bir duyarlılığ1, bir annenin çocuğunun ölümü karşısındaki çığlığı dile getirdiği için önemli bir şiirdir. Ancak Akif'in her şeyden önce "cemiyetçi şair" olduğunu, ondan başka "içinde yaşadığı cemiyeti bu kadar geniş şekilde eserlerine aksettiren başka şair”imiz olmadığını belirtmek gerekir (Timurtaş, 2006: 40). Zaten Akif sosyal meseleleri ele alan şiirlerinde asıl başarısını göstermiş, "kendisine özgü bir dil ve üslup" bulmuş, ferdî duyarlılıkları yansıttığı şiirlerinde ise bunun gerisinde kalmıştır. Kendisi de daha sonra bu tür şiirler yazmamış, bir nevi bunun ayırdına varmıştır (Gökçek, 2013: 28). Akif, özellikle içtimai mevzuya sahip şiirlerinde bir Sahyun Nebisi ${ }^{14}$ kadar "sert ve haşin" bir üsluba sahiptir ve tabiri caizse onlar gibi "korkunç kehanetler"de bulunur. Bunun sebebi Müslüman âlemini içinden bulunduğu atalet ve uyuşukluğundan kurtarmaya çalışmak aksi halde başına gelecek felaketlerin büyüklüğünü göstermeye gayret etmektir. Orhan Okay (2015:176), İslam şairi Akif’in karakter özelliklerinden biri olarak kendi kendini tenkit (otokritik) vasfını öne çıkarır. Onun Müslümanları tenkidi ise, hasımlarından daha fazla ve ağırdır. Bunu da onun samimiyetine en büyük delil olarak gösteren yazar, millet olarak en çok ihtiyaç duyduğumuz şeylerden biri olarak kabul eder.

\footnotetext{
14 “Sahyun Nebîleri : İsrail peygamberleri. Üslupları haşin ve serttir. Korkunç kehanetlerde bulunurlar (Meriç, 2004: 327).”
} 
Sezai Karakoç (1978: 41) Safahat'ın yedi kitabının "cemiyet"i belli başlı cepheleriyle ve temel perspektiflerden tanıttığını ve bir plan dairesinde işlediğini belirterek, Safahat'ın panoramik bir bakış açısıyla ele aldığı kavram, konu, olay ve olguları şöyle tasnif eder:

"1-Birinci Safahat (Genel sosyolojik çizgiler-Denemeler)

2- İkinci Safahat, (Süleymaniye Kürsüsünde) spekülatif yapı şiirleri.

3- Üçüncü Safahat, doktrin şiir (Hakkın Sesleri). Değer hükümleri.

4- Dördüncü Safahat (Fatih Kürsüsünde) siyasî yapı (Kadro).

5- Beşinci Safahat ( Hatıralar), karşılaştırmalı tarihî-sosyolojik çizgiler.

6-Altıncı Safahat (Asım), tarihî-destansı yapı, savaş sosyolojisi, potansiyel hâlinde gelecek zaman.

7-Yedinci Safahat (Gölgeler), Metafizik.

Hakkın Sesleri'nde yer alan on şiirin dokuzunda başlık bulunmazken son şiir ise Pek Hazin Bir Mevlid Gecesi başlığını taşır ve bir bakıma Hz. Muhammed'in ruhundan istimdattır. Bir açıdan bu şiirler, başlarında verilen ayet (8) ve hadislerin (1) çıkış noktası olarak ele alındığı, Balkan Savaşları ve onun uyandırdı $\breve{g ̆}_{1}$ dehşet ve düşünceleri, çeşitli meseleler 1 şı̆̆ birer "âyetlere manzum meâl (Kırkkılıç, 2008: 61-70)"niteliğini de haizdir. Ayrıca kitabın sonunda çok değer verdiği Ömer Ferit Kam'ın Safahat'ın üçüncü kitabının neşri dolayısıyla yazdığı bir yazı yer alır.

Hakkın Sesleri, ihtiva ettiği şiirler vesilesiyle Akif’ in “toplum meseleleri karşısındaki duyarlılığını bir kez daha göstermiş" ve onun "Müslümanların büyük içtimai şairi” olarak nitelendirilmesini sağlamıştır (Gökçek, 2011: 43). Zaten Mehmet Akif (Timurtaş, 2006: 42), “edebiyatımızda Namık Kemal ile başlayan içtimaî ve cemiyetçi şiir nevi telakkisinin en kudretli ve en büyük mümessilidir." Özellikle Hakkın Sesleri’nde dini tarafının da içtimaî bir temele dayandığı görülür.

Çok sevdiği memleketinin her gün yüz yüze geldiği felaketler karşısında 1stırap duyan, milletinin düştüğü tefrikalar karşısında feryat eden Akif’ in çığlığı, cehaletin kucağında uyuyan, ahlaken sükût etmiş, yurtlarından sürülen ve acımasızca katledilen ama buna rağmen mazisinden ilham bile almayıp içine düştükleri bu rezil ve zelil duruma katlanan insanımızı sarsmaya yönelir. Gökçek (2005:170-171), Hakkın Sesleri'nde yer alan şiirlerin tamamına yakının Osmanlı ve İslâm dünyasının meseleleri ile ilgili olduğunu, bunun da İslam birliği düşüncesi ile açıklanabilecek bir husus olduğunu kaydeder. Ona göre "bütün Müslümanlar bir millettir ve bu bakımdan karşı karşıya oldukları problemler de ortaktır."

Hakkın Sesleri ${ }^{15}$ kitabının ikinci sırasında yer alan ve başında $N e m l$ süresinin 27. ayetinin ilk yarısı ( İşte sana, onların kendi yolsuzlukları yüzünden ıpıssız kalan yurtları... ) olan bu şiir, “İslâm'ın çiğnenmiş bir diyarı" olan Rumeli’nin (Osmanlı İmparatorluğunun) başına gelen felaketlere, eski ve yeni durumu arasındaki değişiklikleri de göz önüne alarak dikkat çekmek, bu felaketin sebepleri ile bu feci olayda Müslüman sakinlerinin paylarını ortaya koymak amacını güden bir feryat figandır. ${ }^{16}$

\footnotetext{
${ }^{15}$ Kenan Çağan (2011: 157-184), Safahat'ın sosyolojik okumaya oldukça elverişli bir eser olduğunu, bu yönden okurlara zengin bir malzeme sunduğunu ifade eder. Bir bakıma Akif, Safahat'ta şiirle sosyoloji yapmaktadır. Hakkın Sesleri'nde de "Balkan Harbi ekseninde ayyuka çıkan toplumsal çözülme ve yenilgilerin yankısı" açıkça görülür.

${ }^{16}$ Akif, bu şiirinde o dönem Müslümanlarının temel sorunu olan ümitsizliğe ve tefrikaya dikkat çeker. Genelde İslam dünyasında özelde Osmanlı İmparatorluğunda görülen felaketlerin temel sebebi, Müslümanların dinin emir ve yasaklarından uzaklaşmalarıdır. Ümitsizlik, Akif'in yorumuyla Kur'an'da sapkınlık ve küfürle bir tutulur. Çünkü "Bir Müslüman ümitsizliğe düştüğü gibi Cenab-1 Hakk'ın Allah yolunda çalıșanlara vaat buyurmuș olduğu kurtuluşu, selameti, başarıyı, zaferi inkâr etmiş ol[ur].” Akif'e göre "Ümitsizlik tembelliğe, miskinliğe meşru bir şekil vermektir." Bu helak edici illet bir Müslüman için hem dinin hem dünyanın elden gitmesi anlamına gelir. O dönemde Müslümanların esaret altında inlemesine sebep olarak "lanetli ümitsizlik hastalığı"nı gösteren Akif, bu şiirinde de "Müslümanların derdini kendine dert etmeyen Müslüman değildir." Hadis-i Şerif'inin mucibince hareket eder,
} 
Akif, şiirin ilk bölümünde Rumeli'nin dehşetengiz bir panoramasını çizer. Artık onun için bütün vatan bir mezardır ${ }^{17}$. Ziyaretçisi olmayan kimsesiz mezarların arasından geçen herhangi bir yolcu, "yürekler parçalar" birtakım sesler duyacaktır ki "bu matem” etrafa içlerinde ümitsiz ve kalbi kırık insanların yattığı kabirlerden yayılmaktadır. Ümitsizlik ikinci bölümde de devam eder. Şair, içini “yolcu”ya dökmekte ve bu son parçalanışın telafi ihtimalini içinde barındırmadığını itiraf etmektedir. "Fecr-i nâzânı" bekleyen ve sadece uzaktan seyreden insanların, dostların payına "zehr-i hüsrânı" parça parça olmuş dudaklarla içmek düşmüştür. Burada felaketler karşısında birlik olmayan Müslümanları bekleyen kaçınılmaz ve hazin son vurgulanır.

“Geçenler varsa İslâm’ın şu çiğnenmiş diyârından;

Şu yüz binlerce yurdun kanlı, zâirsiz mezarından;

Yürekler parçalar bir nevha dinler reh-güzârından.

Bu mâtem, kim bilir, kaç münkesir kalbin gubârından

Hurûş etmekte, son ümmîdinin son inkisarından?

Evet, son inkisârından ki yoktur cebrin imkânı:

Batıp gitmiş nazarlar beklemekten fecr-i nâzânı!

Nasıl, ey yolcu, bin lâ'net gelip ezmez ki vicdânı;

Dudaklar çâk çâk olmuş, içerken zehr-i hüsrânı,

Uzaktan baktı -koşmak nerde!- milyonlarca yârânı (Safahat, 178)!

Akif, çizdiği korku verici tablonun daha da vahim olduğunu göstermek ister. Bu yüzden şimdi ISsız ve harap olan bu yurdun, mamur zamanlardaki hâliyle mukayesesini yapar. Aradaki fark muazzamdir.

$\mathrm{Bu}$ 1ssız âşiyanlar bir zamanlar candan muazzezdi;

Bu damlar bu baykuş seslerinden çın çın ötmezdi;

Şu kurbağlar seken vâdîde, ceylânlar koşup gezdi;

Şu coşmuş, ağlayan ırmak ne handan gölgeler sezdi;

Bütün mâzîyi bir tufan, fakat, hep boğdu, hep ezdi (Safahat, 179)!

Şairin seslendiği yurdun, bin ocağından bir ziya bile yayılmaz. Dertleşmek emelinde olan "vatansız, hanümansız” garip şair sığınacak bir melce arar ama "Yok!” diyecek bir ses bile yoktur. Karşısında "vatan nâmına bir kabristan” yatan şair, muhitinde dönen dehşetli matemin yüreğine verdiği elemi, hitap ettiği yolcuyla paylaşmak ister. Burada Akif'in çizdiği manzara, diğer Balkan milletlerince

uyuşuk zihinleri sarsmaya gayret eder. Akif, Müslümanların dünyaya hâkim olmasında "birlik" fikrini önemli bulur. Dünyanın her yerinde yaşayan Müslümanların birbirlerinin sıkıntı ve dertlerine duyarlı oldukları dönemin aynı zamanda İslâm âleminin en parlak devirleri olduğuna dikkati çeken Akif, sonra Müslümanların Kur'an'ın emir ve yasaklarına uymakta gevşeklik gösterdiklerini, aralarındaki bağın zayıfladığını, olumlu ve güzel duyguların yerini habis duyguların aldığını birliğin de zayıflamaya yüz tuttuğunu söyler. Bunun sonucunda da dünyanın çeşitli yerlerindeki milletler hep mahvolmuş, zillete düşmüş ve koca bir İslam âlemi parçalanmıştır. (Akif, 2011: 513-529)

17 Mezar-Makber, Mehmet Akif şiirine önemli bir anlam zenginliği katar. Kimi zaman hayatın geçiciliğini, ebedî âlemi, Allah'1 hatırlatan "bir ihtar işaretidir." Kimi zaman da maziyi, maziden alınması gereken ibreti, şehitleri ve sükûneti hatırlatır. Aynı zamanda mezar-makber, "müminlere vergi bir ümit ışığı" gibi görünür. Mezar-makber, onun şiirinde zaman zaman karşımıza bir "hatip" kisvesiyle çıkar. Bunun yanı sıra, "asıl gayeye yardımcı bir unsur" olarak belirdiği de olur. Bazen bir vatan parçasında bazen de kaybına ağlanan mukaddes bir eşyada beliren, onlara vurduğumuz mühürdür (Öztürkmen, 1969: 97-108). 
yakılmış yıkılmış Rumeli’nin ve katledilmiş Müslüman ahalisinin acıklı durumunu tasvir eder ${ }^{18}$. Medeniyet dairesinde yer alan bu milletlerin yaptıkları karşısında semanın ruhu ezilir arzın kalbi parçalanırken, bu katliamın sorumluları insaniyet namına bundan hiç suçluluk duymazlar. Katledilen halkın tek suçu Müslüman olmaktır.

(...) Azıcık kurcala toprakları, seyret ne çıkar:

Dipçik altında ezilmiş, paralanmış kafalar!

Bereden reng-i hüviyetleri uçmuş yüzler!

Kim bilir hangi şenâatle oyulmuş gözler!

"Medeniyyet" denilen vahşete lâ'netler eder,

Nice yekpâre kesilmiş de sırıtmış dişler!

Süngülenmiş, kanı donmuş nice binlerle beden!

Nice başlar, nice kollar ki cüdâ cisminden!

Beşiğinden alınıp parçalanan mahlûkat;

Sonra, nâmusûna kurbân edilen bunca hayat!

Bembeyaz saçları katranlara batmış dedeler!

Göğsü baltayla kırılmış memesiz vâlideler!

Teki binlerce kesik gövdeye âid kümeler:

Saç, kulak, el, çene, parmak... Bütün enkâz-ı beşer.

Bakalım, yavrusu uğrar mı, deyip, karnından,

Canavarlar gibi şişlerde kızarmış nice can!

İşte bunlar o felâket-zedelerdir ki, düşün,

Kurumuş ot gibi doğrandı bıçaklarla bütün!

Müslümanlıkları bîçârelerin öyle büyük

Bir cinâyet ki: Cezâlar ona nisbetle küçük (Safahat, 179-180)!

Bütün bu vahşet manzarası karşısında âlem-i İslam'ın uyuşukluktan ve ataletten başını kaldırmaması Akif'i oldukça kızdırır ve üzer. Daha önce din, vatan uğruna bu topraklarda perişan naaşlarını bırakan ruhlara seslenen şair, onların da bu elem verici manzarayı görmelerini ister. Onlardan bütün bu fecaat karşısında kılını kıpırdatmayan "leşten daha hissiz, daha kokmuş" insanımızın "çehre-i murdârına, Şark'ın cephe-i lâkaydına, Ehl-i Salîb-in hayâsız yüzüne" ve "asrın maskeli vicdanına" tükürmelerini ister. $\mathrm{Bu}$ vahşette sorumlu olanların dairesini böylece genişleten şair, yabancılaşmış aydınlarımıza da veryansın eder.

(...) Bakmayın, hem tükürün çehre-i murdârımıza!

\footnotetext{
${ }^{18}$ Balkan Savaşları ve sonrasında Rumeli’nin yakıp yıkılışı ve göçler, edebiyatımızın en dokunaklı sayfalarını teşkil eder. Türk Edebiyatının şiir, hikâye, roman, tiyatro ve anı türlerinde bu konuda birçok eser verilmiștir. Araștırmacı Haluk Harun Duman, Balkanlara Veda adıı kitabında, 1912-1914 yılları arasında 280 civarında şiir yazıldığını belirtir. Bu şairlerden biri de, genel olarak Hakkın Sesleri kitabı ile Mehmet Akif'tir. Ziya Gökalp, Rıza Tevfik, Tahir'ül Mevlevi, Yahya Kemal, Halide Edip, Şair Nigar Hanım, Aka Gündüz bu şairlerden bazılarıdır. Bu şiirler ve diğer eserlerin de birer çığlık olduğu ileri sürülebilir. Genellikle de Akif'in çığlığı ile aynı düşünceleri ihtiva ederler. Nesime Ceyhan, 1908-1918 arasında Balkan Savaşlarıyla ilgili olarak yazılan 68 hikâye tespit emistir. Bu hikâyecilerden bazıları Ömer Seyfettin, Aka Gündüz, Kazım Nami'dir. Romancılar arasında Hüseyin Kami, Vassaf Kadri, Halide Edip, Yakup Kadri, Reşat Nuri, Samiha Ayverdi vb. sayılabilir. Tiyatro eserleri arasında Süleyman Sırrı'nın Gayz, Ahmet Er'in Göçmen, Edirne Müdafaası yahut Şükrü Paşa, Nezihe Araz'ın Savaş Yorgunu Kadınlar adlı piyesleri sayılabilir. Anı olarak Ali Ezger Özyürek'in Bitmeyen Göç, Fazıl Bülent Kocamemi’nin Urumeli'nin Gözyaşları adlı eserleri örnek verilebilir (Yenisoy, 2012: 91-111).
} 
Tükürün: Belki biraz duygu gelir ârımıza!

Tükürün cebhe-i lâkaydına Şark’ın, tükürün!

Tükürün milleti alçakça vuran darbelere!

Tükürün onlara alkış dağıtan kahbelere!

Tükürün Ehl-i Salîb’in o hayâsız yüzüne!

Tükürün onların aslâ güvenilmez sözüne!

Medeniyyet denilen maskara mahlûku görün:

Tükürün maskeli vicdanına asrın, tükürün!

Hele i'lânı zamanında şu mel'un harbin,

"Bize efkâr-1 umûmiyyesi lâzım Garb'in;

O da Allah'1 birakmakla olur ${ }^{19}$ " herzesini,

Halka îman gibi telkin ile, dînin sesini

Susturan aptalın idrakine bol bol tükürün!...

Yine hicrân ile çılgınlığım üstümde bugün...

Bana vahdet gibi bir yâr-1 müsâid lâzım!

Artık ey yolcu bırak... Ben, yalınız ağlayayım (Safahat, 180)!

\section{4. "FİRAKLI BİR NAĞME" YA DA MAVERAî BİR ÇIĞLIK OLARAK HİCRAN}

1923-1925 yılları arasında Mısır'da bulunan Akif, dönüşünde bir müddet İstanbul'da kalır. Sonra Misır'da 1926'dan 1936'ya kadar sürecek bir gurbet dönemi yaşar. Son kitabı Gölgeler'de yer alan, bazıları Mısır'a gitmeden çoğunluğu da Mısır'da yazdığı şiirleri daha önceki şiirlerinden muhteva olarak oldukça farklıdır. Şair artık içtimai meseleleri öncelemeyen daha çok dinî - lirik şiirler kaleme almaya başlar.

Mısır'da yazdığı şiirlerden, özellikle birbiri ardına kaleme aldığı Gece, Hicran ve Secde şiirleri lirizm bakımından en coşkun eserleri olarak kabul edilir ${ }^{20}$. Bir bakıma "düştüğü ye'sin verdiği 1ztıraptan kurtulmak için, maddî varlığından nasıl uzaklaşmaya çalıştığını, mistique bir şahsiyete büründüğünü”

\footnotetext{
${ }^{19}$ Mehmet Akif'in bu dizelerle 1908'de Reinhardt Dozy'nin Tarih-i Islâmiyet kitabını Türkçeye tercüme eden özelde Abdullah Cevdet'i genelde Garpçıları eleştirdiği söylenebilir. Bunun için Sırat-1 Müstakim'in 3 Mart 1910 tarihli sayısında, İslam dinine aykırı içeriğinden dolayı yasaklanan bu kitabı savunmak için bir yazı kaleme alan ve bunu gazetesinde yayımlayan Ebuzziya Tevfik'e hitaben yazdığı “Açık Mektup (Akif, 2011: 79-85)” adlı yazısında, hem Ebuzziya Tevfik'in bu girişimini hem de Abdullah Cevdet'in görüşlerini tenkit eder. Bu kitabın iyi niyetli bir eser olmadığını, "Ey Müslümanlar, din diye sarıldığınız şeyin akıllar için, fikirler için ne müthiş bir ayak bağı olduğunu anlayınız. Daha ne zamana kadar böyle hurafelere esir olup kalacaksınız?" beyanında bir çeviri olduğunu ifade ederek, eserin baştan sona "yalan dolu bir kitap" niteliğini gösterdiğini belirtir.

Hanioğlu (1981: 326-341) Bir Siyasal Düșünür Olarak Doktor Abdullah Cevdet ve Dönemi adlı çalıșmasında söz konusu eseri çevirmekle "doğrudan dinin gereksiz ve bilim dişı olduğunu ispata çalışmak ve onun yerine biyolojik materyalizmi önermek düşüncesi”"nin etkili olduğunu söyler. "Din avamın ilmidir, ilm havasın dinidir." düşüncesini benimseyen Abdullah Cevdet, İslam'a özellikle "toplumsal ilerleme açısından" çeşitli eleştiriler yöneltmesine karşın "İslâm dininin olumlu toplumsal içeriğinden" dolayı ondan yararlanmayı düşünür. Bu içerik yardımıyla yeni bir "ethic" yaratma işine girer. Bu "ethic"in oluşturulması için dinden ziyade biyolojik materyalizmden faydalanacaktır. $\mathrm{Bu}$ durum, Abdullah Cevdet'i "Bahailik gibi aşamalar" önermeye zorlar. Hanioğlu'na göre "Dinin arka plana geçtiği bir Türk toplumu düşüncesi Abdullah Cevdet'in 'utopia'sının önemli parçasından birisidir. Ve bu" utopia" Batılılaşma tezleriyle birlikte 1923 sonrası Türkiye Cumhuriyeti’nin resmi ideolojisi ile büyük benzerlik gösterir. Abdullah Cevdet, İslamcılar'ın "Batının ilim ve sanatını almak" düșüncesindeki eklektik tavrının karşısındadır ve Tunaya (2014: 70)'nın belirttiği gibi Batı medeniyetini bir bütün olarak görüp "gülü ve dikeniyle” almaya mecbur olduğumuz tezini savunurlar.

${ }^{20}$ Okay (1989:122-142), Akif’ in asıl sanatkâr ve şair mizacını, dua karakterindeki şiirlerinde bulabileceğimizi söyler. Duanın, onun şiirlerinde iki farklı tezahürü olduğunu belirten Okay, ilkinin "gelenekten gelen, alışılmış ve ritüel bir ibadetin zarurî bir parçası gibi” olduğunu, ikincisinin ise mistik ve metafizik derinliği olan şiirlerde karşımıza çıktığını ifade eder. Gölgeler'de yer alan Gece, Hicran ve Secde şiirlerinin, onu mistik-lirik bir şair olarak değerlendirmemizi gerektirdiğini kaydeder. Tasavvufa meyletmeyen Akif'in, bu üç șiir sebebiyle hakkındaki hükmü değiștirmemiz ya da tashih etmemiz lazım geldiğini ileri sürer. Çünkü bu șiirlerde Akif, tasavvufî bir hâl yaşadığını tenkit ettiği mutasavvıfların terimleriyle anlatır. Okay, bu düşüncesinin sonuna şu kaydı da düşer: "Hasan Basri Çantay kendisine 'Hayret üstad, siz vâdiyi değiştirmişsiniz' dediği zaman ona ' Hayır değiştirmedim. Benim vâdim zaten bu idi. Bütün öteki şiirlerimi cemiyete faydalı olsun diye yazdım’ cevabını vermiştir.”
} 
gösteren bu şiirler, onun sanatında önemli bir noktayı işaret eder (Tansel, 1945: 125-129). Bu şiirleri tam anlamıyla birer tasavvufî şiir olarak kabul etmek güçtür. Zaten Gökçek (2013: 83-84) de Akif’te, kendisinin beyanına rağmen, bu üç şiirinden yola çıkarak tasavvufa yöneldiğini kabul etmenin mümkün olmadığını ifade eder. Akif'in bu şiirlerinde var olan tasavvufa yöneliş düşüncesinin, Tansel'in de yukarıda belirttiği gibi, "ruhsal bir zorunluluktan kaynaklanan” bir eğilim olduğu görülür ${ }^{21}$.

Yukarıda belirttiğimiz Hicran şiiri, Akif'in yakın dostu Eşref Edip'in anlattığına göre çok sevdiği ve heyecanla okuduğu bir neşidesidir. Akif, okuduğu şiiri anlamadığını söyleyen Eşref Edip'e biraz kızar ve izah etme gereği duyar:

Bu bir mab'edse, çırçıplak yakışmaz, sonra gâyet loş;

Gelen: Ma’bûd; 1şık bul, yaygı bul, git başka yerden, koş!

Hemen bir kandil aldım komşulardan, bir de seccâde;

Dedim: "Gel şimdi mihmânım, sa'âdet-gâhın âmâde."

Ne yanlışmış hesâbım: Hiç kapımdan geçmez oldun bak! (Safahat, 445)

Akif'in işaret ettiği gibi burada “ma’bed” kalp’tir. Şair, kalbini mabut gireceği için “ilim ve irfanla süslemiştir” ama aldanmıştır. “Orası ilimle, zahirî şeylerle aydınlanmıyor, süslenmiyor”dur. Şair, sonra bu gafletinden sıyrılıp kendini varlıktan soyutlar (Edip, 1960: 260-261). “(...) Kendisinde bütün emirlerdeki hakikatin künhü tecelli etsin diye hazırlanmış bir ayna (Gazali, 1974: 29-39)" olarak bahsedilen “kalp” Kur'an'da çeşitli ayetlerin yanı sıra, bazı hadislerde ${ }^{22}$ de ele alınmıştır. Benzer imge Akif'in çok severek okuduğu Mevlana ${ }^{23}$ ile Yunus Emre'de görülebilir.

Akif'in bu şiiri, gurbette yazılmıştır. Öncelikle memleketinden ayrıdır, yani Mısır'dadır. Bununla birlikte "Hicran" İslam düşüncesinde ele alındığı şekliyle, insanın ebedî yurdu olan cennetten dünya gurbetine atıldı̆̆ 1 fikrine de göndermede bulunur. İşte Akif, biraz fizikî gurbetin ama çokça manevi

\footnotetext{
${ }^{21}$ Ekrem Demirli (2011: 153) ise Akif şiirinde tasavvufla ilgili olarak şunları söyler: “ “Akif, özellikle tasavvufi hayatın vecd ve manevi derinliğine karşılık geldiği ölçüde metafizik’e dair yönelimleri olan, ancak bunu ortaya koyabilecek nazarî ve nesnel bir dile ve bu dili besleyecek donanıma sahip olmayan bir şair olarak görünmektedir." Benzer düşünceleri daha önce Ali Nihat Tarlan (1971: 48-49) da dile getirmiştir. Akif'in “tamamen şeriata bağlı olup tasavvufa ruhen yanaşmış bir insan” gibi göründüğünü kaydeden Tarlan, tasavvufun onda bir iç meselesi olduğunu belirtir. Ancak özellikle Gölgeler'de yer alan bazı şiirlerinin, onu tasavvufta bir irtifa olarak kabul etmek için yeterli olduğunu dile getiren yazar, Akif'in "ruhunun bu tarafını ifşsa etmediğini" bununla birlikte onda gördüğümüz "çok geniş ve şuurlu tesamühü[n]" bu cephesinden kaynaklandığını ileri sürer. Yine talebesi ve yakın dostu Muallim Mahir İz (2014:172) ise Akif' in hiçbir zaman tasavvufa karşı olmadığını, gerçek tasavvuf ve tasavvuf erbabı hakkında kötü söz sarf etmediğini ifade eder. Bunun yanı sıra Akif’in Şems-i Mağribi Divanı, Hatifî İsfehânî’nin “Ki yekî hest ü hîç cüz û/Vahdehû lâ ilâhe illâ hû (Kendisi vardır, ondan başka hiçbir şey yoktur. Tek Allah ancak odur)" olduğu gibi tasavvufî eser ve beyitleri okurken manevi bir vecde ve neşveye büründüğünü kaydeder.

Mehmet Demirci (2011:299-321) de Akif'in şiirindeki tasavvufi eda ile ilgili olarak, yukarıda belirtilenlerle genel olarak benzer düșüncelere sahiptir. Akif'in yaşayıș bakımından tasavvufla doğrudan bir ilgisi olmadığını söyleyen Demirci, yetiștiği ortamın onu tasavvufî anlamda etkilediğini belirtir. Akif'in "akılcı bir din zihniyetine" sahip ve "tekke Müslümanı olmaktan çok cami Müslümanı” olan Akif’in özellikle ömrünün sonuna doğru yazdığı şiirlerinde tasavvuf düşünce ve inanışının izlerini görmenin mümkün olduğunu söyler ama bunun sebeplerini irdelemez.

${ }^{22}$ Ahzab/72. ayette "Biz emaneti göklere, arza ve dağlara teklif ettik de onlar bunu yüklenmekten çekindiler, ondan korktular da onu insan yüklendi." "Kalp”ten insanı diğer yaratılmışlardan ayıran ve emaneti yüklenmeye hazır hale getiren "rabbanî ve şerefli” bir şey olarak bahsedilir. Yine bazı ayetlerde:

“Allah kime hidayet etmeyi dilerse onun göğsünü İslâm'a açar, gönlüne genişlik verir.(En'am/125);

Allah'ın İslâm nûruyla kalbine genişlik verdiği kimse, kalbi mühürlü, nûrsuz kimse gibi midir? Elbette o, rabbinden bir hidayet üzeredir. O halde vay o Allah'ın zikrinden kalpleri katı olanlara! Onlar apaçık bir sapıklık içindedirler.(Zümer/22)” Kalp ile iman arasında doğrudan bir ilişki kurulmuştur.

Bazı hadislerde de "kalp"in Allah'ın evi olarak kabul edildiği açıkça belirtilir: "Ey Allah'ın Rasûlü! Allah nerededir? Yerde mi, gökte mi?' Hz. Peygamber cevap olarak şöyle buyurmuştur: 'Mü'min kullarının kalplerinde!” Bir hadîs-i kudsî'de Allah Teâlâ'nın şöyle buyurduğu rivayet edilmiştir: "Benim arzım ve semâm beni istiâb edemedi. (Fakat beni) sâkin, yumuşak ve mü'min kulumun kalbi istiâb etti."

${ }^{23}$ Kara (2005:483-523).”Mevlana’nın Mesnevisinde Kalp-Gönül” Tasavvuf İlmî ve Akademik Araștırma Dergisi. Ankara.Y. 6. S. 14, ss. 483-523. ss.20-28.
} 
ayrılığın verdiği yakıcı bir duyguyla "firaklı nağme”lerle Allah’a yalvarmaktadır. Gerçi bu fizikî gurbet, birtakım hayal kırıklıklarının neticesi olarak "gönüllü bir sürgündür"', ama firkatin ateşi, manevi ayrılıktan doğan ıstırabı artırmaktadır.

Kalbini Allah'tan gayrısından yani masivadan temizleyen şair, bu sebeple artık, bir rahmet tecellisi beklemektedir. Artık bir insan olarak başlangıçta toprak saflığına irca etmiştir. Ferdî, içtimai ve uhrevî anlamda peşinde koştuğu şeylerin neticesi hep “hüsran”la neticelenmiştir. Bir bakıma münacaat olarak kabul edilebilecek bu şiir, şairin bağışlanma ve kavuşma iştiyakını dile getirir. Havf ve reca arasındaki şair, yine bu yakarışta yurdunu, milletini ihmal etmez.

"İlâhî! Söktüm attım, işte hücrem şimdi çırçıplak;

Ne afâkında tek kandil, ne mihrâbında seccâde;

Ezelden bildiğin toprak, bütün varlıktan âzâde.

Serilmiş secdelerdir bekleyen yerlerde mihmânı;

Bu üryan şu'le dersen, sînemin pâyansız îmânı.

İlâhî! Bir hata ettimse, elvermez mi hüsrânım?

(...) Şu öksüz yurda bir gülmez misin? Hâlâ yetimindir;

Bütün yangındı indirdiklerin, bir gün de nûr indir.

Hayır, ben handeden geçtim, celâlin etmesin tehdîd,

Açar haşyetle donmuş her sücudum renk renk ümmîd (Safahat, 445).”

Akif, bunaldığı anlarda bir melce olarak yönünü Allah'a döner. Ama duasının Allah katında karşılık bulmadığını, kalbinde ilahî nurun tecelli etmediğini düşünür. Bu durum ondaki hicranı âdeta cehennemî bir ateşe çevirir. Bununla birlikte bağışlanmak diler. Bunun için yaşlar dökmüş, kalbini “mâsivâ"dan arındırmıştır. Bekleyiş uzadıkça ya da kavuşma anı geciktikçe feryadı gökyüzünü kaplar. Burada Akif, dolaylı olarak tasavvufta ve Mevlana düşüncesinde gördüğümüz "şeb-i arûs” düşüncesi yani kısaca "gerçek hayat ölümdedir." görüşü işlenir (Demirci, 2000: 9-16). Akif, varlığın ruha yük olan bütün bedenî arazlarından sıyrılmış, mağfiret kapısı önünde rahmetin tecelli etmesini ya da kavuşmayı beklemektedir.

"İlâhî! Pek bunaldım, nerde nurun? Nerde gufrânın?

Cehennem gezdirip dursun mu âfâkımda hicrânın?

Evet, gafletti sun'um, lâkin insan gaflet etmez mi?

Yıkandım bir ömürdür döktüğüm yaşlarla, yetmez mi?

Gel artık, mâsivâ yok, şimdi yurdum Tanrı yurdumdur:

Tüten hücremde îmânım, yatan, yer yer sücudumdur.

Ne irfânımda bir iz var, ne vicdânımda, ey Yezdan,

O seccadeyle kandilden sinen bigâne ruhundan (Safahat, 446-447).”

Firakın verdiği elem, Akif'i söylemeye mecbur kılar. Allah tecelli etmedikten sonra kalbin, mihrabın, haşyet, vecd vb. unsurların hiçbir anlamının olmadığını âdeta birer "enkâz-1 îman”a dönüştüğünü, secdelerin mahzun ve meyus kaldığını terennüm eden şair, böyle bir mabedin ya da kalbin

\footnotetext{
${ }^{24}$ Mehmet Akif' in “gönüllü sürgün’üne dair ortaya çıkan yeni belgeleri ihtiva eden bir kitapta, bu süreç detaylarıyla anlatılır.
} (Coşkun, 2015). 
"târumâr" olmasını diler. Şair, maddi ve manevi anlamda o kadar yalnızdır, ayrılık (memleket/yurtahiret/Allah) o kadar uzun sürmüştür ki dayanmasına imkân kalmamıştır. "Aşk derdinin çaresi visaldir." fehvasınca bir an önce Allah'a kavuşmayı ister.

İlâhî sinemin çınlar durur yâdınla eb'âdı

Ne yapsın âbidin sensiz bu viran vahşet-âdâbı?

Nedir ma'nâsı, Ma'bûd olmadıktan sonra, mihrâbın,

Rükû'un, haşyetin, vecdin, bütün bîçâre esbâbın?

Harâb enkâz-1 îmandır, yatar haybetle yerlerde,

Ne bekler, sen geçerken pây-mâlin olmayan secde?

Bütün cevviyle, evrâmıyle insin, târumâr olsun,

Nedir ma'nası bir kalbin ki, âfâkında sen yoksun!

Güneşler geçti, aylar geçti, artık gel ki, mihmânım,

Şuhûdundan cüdâ îmanla yoktur kalmak imkânım (Safahat, 446).

Hicran şiiri aşık-maşuk, kul-mabud arasında cereyan eden, birincilerin bir arzuhali, bağışlanma ve mağfiret isteğinin çığlığa bürünmüş hâli olarak okunabilir. Hicran ve bu devrede yazılanlarla Akif' in şiiri, son kavsini yapar. Akif ve şiiri taşıdığı nitelikler bakımından, "kendi gök kubbemiz"de ebediyete kadar çınlayacak bir çı̆̆lığa dönüşür.

\section{SONUÇ}

Modern Türk şiirinin realist bir muhteva kazanmasında önemli katkıları olan Mehmet Akif, aynı zamanda aruzu Türkçeye başarılı bir şekilde uyguladığı, konuşma dilindeki doğallı̆̆ı şiir dilinde yansıtan başarılı örneklerle bu yolda önemli bir merhale bir teşkil eder.

Akif, dile büyük önem verir. Safahat, aynı zamanda onun dilde sade söyleyişi esas alan bu anlayışının uğraklarını bize verir. Edebiyatımıza şiirle düşünme biçimini sokan Akif, Safahat ile toplumumuzu çeşitli zaviyelerden teşrih masasına yatırır. Bu açıdan Safahat'ı "muayyen bir nokta-i nazardan tasvir edilen bir manzum romana” benzetebiliriz. Bu eserin belirli bir dünya görüşünün 1şığında, “Kur-an ve Din merceğinden” hareketle yazıldığı açıktır. Akif, her şeyden önce İslâmcı bir düşünürdür ama onda bu düşünce ithal bir meta değildir. Onun İslamcılığı kaynaklarını ve gücünü "sokaktan, aileden klâsik kültürden, toplumdan, devletin sarsıntılı hâlinden ve nihayet kendinden almıştır.”

Akif, "İslâm devleti birliğinin savunucusu” anlamında bir İslâmcı ya da panislamist değildir. Akif bir Müslümandır ve imanının gereğini yapmıştır. Akif'in Berlin'de bulunuşunu, Necid çöllerine gidişini, Milli Mücadele için fikrî ve fizikî mücadelesini hep bu çerçevede değerlendirmek icap eder.

Araştırmacılar Akif’i, “terennümün değil, çığlığın virtüözü” olarak kabul eder. Çok kere acı ve ümit dolu olan bu çığlık, bazen Nuh Peygamberinki gibi muhataplarını kurtuluşa çağırırken bazen de Sahyun Nebilerininki kadar korkunç kehanetlerde bulunur. Akif'in çığlığı, devrin çeşitli gelişmeleri ile yakın bir ilişki içindedir ve bunlardan ayrı ele alındığında anlaşılamaz. Bu çığlığın dış yapı unsurlarını sanat telakkisi, yazma tekniği ve lisan karşısındaki tutumu oluştururken; Kur’an ve iman anlayışı, vatan sevgisi ile müspet ilimler karşısındaki tavrı da muhtevasını kurar.

Safahat'ı aslında bütün olarak bir çığlık kavramı eşliğinde okuyabiliriz. Bu çığlık yahut feryadın genel olarak ferdî-içtimai-metafizik bir yön izlediği söylenebilir. Her şeyden önce bu şiirler, bir şair 
tarafından dile getirildiği için bir ferdî tahassüs ve fikirler yumağıdır. Bunun yanı sıra toplumun ve milletin buhranlı zamanlarına, yöneticilere, yozlaşmış düşüncelere, atalete, ümitsizliğe ve geleceğe dönük bir isyan ve haykırıştır. Bazıları Birinci Safahat'ta yer alan ama çoğunluğu hayatının son yıllarında yazdığı şiirleri ise, ülfetten uzlete çekilmeye mahkûm edilmiş, artık gözünü maveraya çevirmiş merdümgiriz bir şairin öte âleme seslenen verimleridir.

I.Safahat'ta yer alan "Bir annenin çığlığına eklenmiş bir çı̆̆lık" gibi inleyip duran Selma şiiri, konusu bakımından ferdî bir meseleye eğilir. Bir annenin çocuğunun ölümü karşısında duyduğu derin keder ve elemi anlatan bunun gibi şiirleri, daha sonraki Safahat'larda neredeyse görmeyiz. Onun şiiri genellikle içtimai şartların belirlediği bir zemin üzerinde yükselir. Selma, "yürek burkan vaveyla ya da hazin bir veda"dır. Akif bu şiirinde aslında insanın şuurunu burkan bu ontolojik meseleyi, fertlerde yarattığı inikâslar yönüyle ele almaktadır. Ayrıca hekimlik ve analık kurumu, bazı yönleriyle tenkit edilir.

Şiirinin asıl zembereğini kuran içtimai yapı unsurları, en belirgin olarak Safahat'ın üçüncü kitabı olan Hakkın Sesleri'nde görülür. Akif, Balkan Savaşları ve sonrasını anlattığı bu şiirlerde "kendisine özgü bir dil ve üslup" kurmuş, ferdî temalı şiirlerde bunun gerisinde kalmıştır. Bu şiirlerinde çeşitli ayet ve hadisleri bir kalkış noktası olarak benimseyen şairin feryadı, sosyolojik bir muhteva kazanır.

“Geçenler varsa İslâm’ın şu çiğnenmiş diyarından” mısraıyla başlayan bu şiir, Rumeli için yakılan ağıtların en hüzün verici olanlarındandır. Aynı zamanda bu şiirde, "İslâm'ın çiğnenmiş bir diyarı" olan Rumeli’nin (Osmanlı İmparatorluğunun) başına gelen felaketler, eski ve yeni durumu arasındaki değişiklikler temel alınarak, bu felaketin sebepleri ile bu feci olayda Müslüman sakinlerinin paylarını ortaya koymak amacı güdülür. Dinine ve halkına yabancılaşmış aydınlar da şiddetle yerilir. Bütün vatan sathının bir mezar gibi göründüğü bu devrede Akif, genelde Müslümanları özelde insanımızı içine düştükleri ümitsizlik ve atalet batağından çıkarmak için sürekli feveran eder. Bir yüreğin kârı olamayacak bir elemi yaşamak, tatmak onun yaşaması gereken kaderidir.

Yedinci Safahat/Gölgeler Akif' in daha çok öte âleme seslenen şiirlerini ihtiva eder. Bunlardan "Firaklı Bir Nağme ya da Maverai Bir Çığlık" olarak kabul edilebilecek Hicran adlı şiiri, tasavvufî açıdan ele alınmaya elverişli bir anlam çerçevesi sunar. Dini yozlaştıran ve sığlaştıran tasavvufî kişi ve kurumları hedef alan Akif, Muhammet İkbal gibi bir tasavvufi sistem kuramamıştır. Bununla birlikte yetiştiği ortamın ve aldığı eğitimin etkisiyle eserlerinde bazı tasavvufî pırıltılar görülebilir. Bu şiirdeki "mabed" kavramı, tasavvuftaki “Allah'ın evi” ve “ayna” imgelerine yakın bir anlayışla ele alınmıştır. Kalbini masiva ile dolduran şair, Allah tecelli etmediği için meyustur, hüsrandadır. Kalbini Allah’tan başkasına kapayan şairin ahı, beklenen tecellinin zuhur etmemesi sebebiyle gökleri tutar. Bir münacaat olarak görülebilecek bu şiir, gurbeti ve bundan doğan hicranı (yurt-ülke/ahiret yurdu) çeşitli açılardan ele almayı mümkün kılan bir zemin üzerinde yükselir, kendi gök kubbemizde ebediyete kadar çınlayacak sayhaya dönüşür.

\section{KAYNAKÇA}

Akbalık, Esra (2013). Yunus Emre'nin şiirlerinde 'gönül' imgesi. Uluslararası Sosyal Araştırmalar Dergisi, C.6, Say1 26, (20-28).

Akyüz, Kenan (1999). Modern Türk edebiyatının ana çizgileri 1860/1923. İstanbul: İnk1lâp Kitabevi.

Arslan, Fatih (2009). Metaforik tercihler bakımından Akif'i okuyabilmek. Uluslararası I. Mehmet Akif Sempozyumu Bildirileri Kitabı, Burdur, (259-264). 
Beyatl1, Yahya Kemal (2010). Edebiyata dair. İstanbul: İstanbul Fetih Cemiyeti Yayınları.

Cerrahoğlu, A. (1964). Bir İslâm reformatörü Mehmet Akif. İstanbul: İstanbul Matbaas1.

Coşkun, Muharrem (2015). İlk kez yayınlanan belgelerle 'vatanında cüda' istiklal şairi/kod adı: irtica906. İstanbul: Yeditepe Yayınevi.

Cündioğlu, Dücane (2007). Bir Kur'an şairi/Mehmed Akif ve Kur'ân meâli. İstanbul: Etkileşim Yayınları.

Çağan, Kenan (2011). Mehmet Akif'te toplum: ya da şiirler sosyoloji. Vefatının 75. Yılında Uluslarası Mehmet Akif Ersoy Sempozyum Bildirileri, (Hazırlayan: Vahdettin Işık). İstanbul: Zeytinburnu Belediyesi Kültür Yayınları, (157-184).

Çitçi, Sinan (2013). Mehmet Akif'in şiirlerinde ağlamalar. Türk Kültürü Íncelemeleri, C:29, (225-255).

Demirci, Mehmet (2000). Ölümdeki hayat: tasavvuf düşüncesinde hayat. Tasavvuf Dergisi, Sayı 4, (916).

(2011). Mehmet Akif ve Safahat'ta tasavvuf. Hakikat Adamı Mehmet Âkif'e Armağan. (Editör: Mehmet Bayyiğit), Konya: Erman Ofset, (299-321).

Demirli, Ekrem (2011). Mehmet Akif'in şiirinde tasavvuf: Safahat'1 bir tasavvuf-ahlak metni olarak okumak. Vefatının 75. Yılında Uluslarası Mehmet Akif Ersoy Sempozyum Bildirileri, (Hazırlayan: Vahdettin Işı), İstanbul: Zeytinburnu Belediyesi Kültür Yayınları, (137-153).

Düzdağ, M.Ertuğrul (1987). Mehmed Âkif hakkında araştırmalar/hayatı-eserleri-fikirleri-şahsiyetizamant-çevresi. İstanbul: MAM.

Edib, Eşref (1960). Mehmet Âkif/hayatı - eserleri ve yetmiş muharririn yazıları. Birinci Cilt. İstanbul: Sebilürreşad Neşriyatı.

Enginün, İnci (2004). Yeni Türk edebiyatı araştırmalar. İstanbul: Dergâh Yayınları.

Erişirgil, Mehmet Emin (1986). Íslamcı bir şairin romanı. (Yayına hazırlayanlar: Aykut Kazancıgil-Cem Alpar). Ankara: Türkiye İş Bankası Kültür Yayınları.

Eroğlu, Ebubekir (2011). Modern Türk şiirinin doğası. İstanbul: YKY.

Ersoy, Mehmed Akif (2010). Safahat. (Neşre Hazırlayan: M. Ertuğrul Düzdağ). Ankara: TDV Yayınları. -(2011). Düzyazılar/makaleler-tefsirler-vaazlar. (Hazırlayan: A.Vahap Akbaş). İstanbul: Beyan yayınlar1.

Gazâlî, İmam (1974). İhyâ̂ 'Ulûmi'd-dîn. Cilt:3 Rub'u'-l Mühlikât. (Tercüme: Ahmed Serdaroğlu). Ankara: Bedir Yayınevi.

Gökçek, Fazıl (2005).Mehmet Akif'in şiir dünyası. İstanbul: Dergâh Yayınları. (2011). Bir medeniyetin şairi Mehmet Âkif. Ankara: TDK.

Hanioğlu, M.Şükrü (1981). Bir siyasal düşünür olarak Doktor Abdullah Cevdet ve dönemi. İstanbul: Üçdal Neşriyat.

İnal, İbnülemin Mahmud Kemal (1988), Son asır Türk şairleri. Cilt:1. İstanbul: Dergâh Yayınları. İz, Mahir (2014), Üstadım Mehmed Âkif/Muallim Mâhir İz’in hatıraları. (Hazırlayan: M. Ertuğrul Düzdağ). İstanbul: Bağcılar Belediyesi Kültür Yayınları.

Jäschke, Gotthard (1972). Yeni Türkiye'de İslâmlık. (Çev.Hayrullah Örs). Ankara: Bilgi Yayınevi. Kaplan, Mehmet (2013). Şiir tahlilleri 1/Tanzimat'tan Cumhuriyet'e. İstanbul: Dergâh Yayınları. Kara, İsmail (2011). Türkiye'de İslâmcılık düşüncesi 1/metinler-kişiler. İstanbul: Dergâh Yayınları. 
Kara, Kerim (2005). Mevlana'nın Mesnevi'sinde kalp-gönül. Tasavvuf İlmî ve Akademik Araştırma Dergisi, Y. 6, Sayı 14, (483-523).

Karakoç, Sezai (1978). Mehmet Âkif. İstanbul: Diriliş Yayınları.

Kırkkılıç, Ahmet (2009). Âyetlere manzum meâl. Uluslararası I. Mehmet Akif Sempozyumu Bildirileri Kitabı, Burdur, C:1, (61-70).

Kuntay, M. Cemal (2001). Mehmed Akif. İstanbul: Timaş Yayınları.

Kutay, Cemal (1963). Necid çöllerinde Mehmet Akif. İstanbul: Tarih Yayınları.

Meriç, Cemil (2004). Bu ülke. (Yayına Hazırlayan: Mahmut Ali Meriç). İstanbul: İletişim Yayınları. (2013). Kültürden irfana. (Yayına Hazırlayan: Mahmut Ali Meriç). İstanbul: İletişim Yayınlar1.

Nazif, Süleyman (2015). Mehmed Âkif. (Hazırlayan: M. Ertuğrul Düzdağ). İstanbul: Kap1 Yayınları.

Okay, Orhan (1989). Mehmed Âkif/ bir karakter heykelinin anatomisi. İstanbul: Akçağ Yayınları. (2010). Batılılaşma devri Türk edebiyatı/fikirler-türler-topluluklar-temalar. İstanbul: Dergâh Yayınları.

(2015). Mehmed Âkif/kalabalıklarda bir yalnız adam. İstanbul: Dergâh Yayınları.

Öztürkmen, Neriman Malkoç (1969). Mehmet Akif ve dünyası/Safahat'ta geçen yapı unsurlarının sitilistik tahlili. Ankara: Altınok Matbaası.

Sevük, İsmail Habib (1930). Edebî yeniliğimiz. İstanbul: Remzi Kitabevi.

Tansel, FevziyeAbdullah (1973). Mehmet Âkif/hayatı ve eserleri. İstanbul: İrfan Yayınevi.

Tarlan. Ali Niha (1971). Mehmed Âkif ve Safahat. İstanbul: Nidâ Yayınevi.

Timurtaş, Faruk Kadri (2006). Mehmet Âkif ve cemiyetimiz. Ankara: Akçă̆ Yayınları.

Topçu, Nurettin (1970). Mehmet Âkif. İstanbul: Hareket Yayınları.

Tunaya, Tarık Zafer (2004). Türkiye’nin siyasî hayatında batılılaşma hareketleri. İstanbul: İstanbul Bilgi Üniversitesi Yayınları.

Yenisoy, Hayriye Süleymanoğlu (2012). 1912-1913 Balkan Savaşlarının Edebiyata Yansıması. Balkan Araştırma Enstitüsü Dergisi, (91-111).

Yetiş, Kazım (2006). Bir mustarip Mehmet Akif Ersoy. Ankara: Akçă̆ Yayınları. 